\title{
Pengaruh Kepemimpinan dan Kompensasi Terhadap Kinerja Karyawan pada Hotel Syariah di Kota Padang
}

\author{
Eka Mariyanti ${ }^{1)}$, Putri Rindung Bulan ${ }^{2)}$, Firman Syakri Pribadi ${ }^{3)}$ \\ ${ }^{1}$ Fakultas Ekonomi dan Bisnis, Universitas Dharma Andalas \\ email: ekamariyanti@yahoo.com \\ ${ }^{2}$ Fakultas Ekonomi dan Bisnis, Universitas Dharma Andalas \\ email: rindungbulan38@gmail.com \\ ${ }^{3}$ Jurusan Manajemen, STIE Sumbar \\ email: adjo_fe@yahoo.com
}

\begin{abstract}
ABSTRAK
Penelitian ini merupakan penelitian asosiatif kausal dengan menggunakan pendekatan kuantitatif yang bertujuan untuk mengetahui Pengaruh Kepemimpinan dan Kompensasi terhadap Kinerja Karyawan pada Hotel Syariah di Kota Padang. Penelitian ini menggunakan variabel kepemimpinan (X1), kompensasi (X2) kinerja karyawan (Y). Unit analisis dalam penelitian ini merupakan karyawan pada hotel syariah di Kota Padang yaitu Hotel Sofyan Inn Rangkayo Basa, New Rasaki Hotel The Sriwijaya Hotel dan The Abidin Hotel. Sampel berjumlah 104 karyawan yang bekerja pada hotel syariah dikota padang, Hasil penelitian ini menunjukkan bahwa, (1) kepemimpinan berpengaruh positif dan signifikan terhadap kinerja karyawan pada hotel syariah di kota padang, 2) kompensasi berpengaruh positif dan signifikan terhadap kinerja karyawan pada hotel syariah kota padang, 3) kepemimpinan dan kompensasi secara bersama-sama berpengaruh signifikan terhadap kinerja karyawan pada hotel syariah di kota padang, dengan nilai Adjusted $\mathrm{R}$ Square sebesar 0,368 atau kepemimpinan dan kompensasi mempengaruhi kinerja karyawan sebesar 36,8\% dan sisanya dipengaruhi oleh variable lain.
\end{abstract}

Kata kunci: Hotel Syariah; kepemimpinan; kompensasi; kinerja karyawan; kota padang.

Detail Artikel :

Diterima : 00 Februari 00

Disetujui : $00 \mathrm{Mei} 00$

\section{Pendahuluan}


Wisata halal atau halal tourism dipandang sebagai cara baru untuk mengembangkan pariwisata Indonesia yang menjunjung tinggi budaya dan nilai-nilai Islami dimana ia merupakan salah satu sistem dalam dunia pariwisata yang diperuntukkan bagi wisatawan muslim yang pelaksanaannya sangat memegang teguh prinsip-prinsip dan aturan syariah.

Meskipun wisata halal merupakan isu yang masih baru, namun wisata halal dianggap sebagai bentuk wisata yang diperkirakan akan menjadi sektor yang paling pesat (Wingett, dan Turnbull, 2018). Wisata halal bukan hanya wisata ke tempat-tempat wisata religi atau ziarah saja, melainkan lebih ke pada pelaksanaannya yang mengedepankan pelayanan berbasis standar halal umat muslim, seperti penyediaan makanan halal dan tempat ibadah. Dalam industri pariwisata terdapat banyak aspek dan pelaku yang terlibat, misalnya hotel dan akomodasi, makanan dan minuman, transportasi, fasilitas ibadah, dan tentu objek wisata itu sendiri. Seluruh aspek ini haruslah tidak bertentangan dengan syariah, sederhananya halal dan menyakinkan.

Seiring dengan berkembangnya ekonomi syariah di Indonesia, pelaku-pelaku bisnis di Sumatera Barat juga tidak mau ketinggalan untuk mengembangkan sektor bisnis di bidang perhotelan dengan menerapkan manajemen berbasis syariah. Menurut Sofyan, (2011), hotel berbasis syariah atau hotel syariah adalah hotel yang dalam penyediaan, pengadaan dan penggunaan produk dan fasilitas serta dalam operasional usaha tidak melanggar aturan syariah, berusaha dengan sistemnya untuk meminimalisasi dan menghilangkan kemungkinan terjadinya penyalahgunaan fasilitas oleh pengguna jasa. Secara operasionalnya, pelayanan yang diberikan di hotel syariah tentunya hampir menyerupai hotel konvensional pada umumnya. Namun konsep hotel ini menyeimbangkan aspek-aspek spiritual Islam yang berlaku didalam pengelolaan dan pengoperasiannya.

Produk dan jasa wisata, serta tujuan wisata dalam pariwisata syariah adalah sama seperti wisata umumnya selama tidak bertentangan dengan nilai-nilai dan etika syariah. Hotel syariah juga mempunyai akomodasi ramah muslim dengan kriteria seperti kamar dan lingkungan hotel bersih, terdapat arah tunjuk kiblat, menyediakan peralatan ibadah untuk muslim, tersedianya informasi waktu solat, terdapat public mushala dengan area laki-laki dan perempuan yang terpisah, kamar mandi dilengkapi bidet atau hand shower, memiliki restoran halal atau tidak terdapat menu non halal, menyediakan makan sahur dan berbuka puasa di bulan ramahan, tidak menyediakan minuman beralkohol pada minibar dan kamar, dan tidak memperbolehkan hewan non halal masuk ke area hotel. Hotel syariah juga merupakan prinsip yang sangat menarik karena menggabungkan antara prinsip agama dan sistem industri. Pada dasarnya pengembangan hotel syariah bukanlah hotel eksklusif karena wisatawan non Muslim juga dapat menikmati pelayanan yang beretika syariah sesuai dengan prinsipnya yang universal dan tidak membeda-bedakan wisatawan muslim dan wisatawan non muslim.

Dalam pengelolaan industri hotel yang bergerak di bidang syariah di Sumatera Barat, diperlukan manajemen pengelolaan hotel yang terorganisasi agar dapat terus bersaing dan bertahan dengan kian ketatnya persaingan industri hotel yang ada sekarang. Dalam mencapai tujuannya, pihak hotel memerlukan sumber daya manusia sebagai pengelola sistem dan karyawan yang mempunyai kinerja yang baik. Menurut Sainaghi, (2010) mendefinisikan kinerja karyawan sebagai perilaku karyawan dan hasil yang sangat penting bagi keberhasilan organisasi. Sumber daya manusia yang kompeten dengan kinerja yang baik juga dapat menunjang keberhasilan bisnis perhotelan, sebaliknya sumber daya manusia yang tidak kompeten dan kinerjanya buruk merupakan masalah kompetitif yang dapat menempatkan perusahaan dalam kondisi yang merugi. Walau bagaimanapun Industri perhotelan di Sumatra Barat lebih optimistis menatap kinerja tahun ini, meski pemulihan ekonomi belum optimal dan kian ketatnya persaingan industri hotel berbintang di daerah itu. General Manager Rocky Hotels Grup Emir Yahya meyakini kinerja tahun ini akan lebih baik dari tahun lalu, didorong proyeksi peningkatan kunjungan wisatawan dan rencana kegiatan pemerintah. "Tahun ini kami lebih optimis. Karena sektor pariwisata juga sudah mulai berkembang, sehingga jumlah wisatawan terutama domestik akan meningkat, juga rencana sejumlah event dari pemerintah daerah," katanya kepada (Faisal, 2017). Menurutnya, kebijakan pemerintah daerah yang memprioritaskan pengembangan sektor pariwisata ikut mendongkrak pertumbuhan ekonomi daerah itu dan meningkatkan kunjungan wisatawan.

Hal ini menyebabkan, kian ketatnya persaingan antara hotel syariah di Sumatera Barat, sehingga pihak hotel berusaha untuk meningkatkan kinerja karyawannya agar lebih baik lagi, Dimana kinerja karyawan juga dipengaruhi oleh kepemimpinan. Kepemimpinan yang dibutuhkan adalah yang mampu mengarahkan dan menggunakan sumber daya manusia yang tersedia secara optimal, Sehingga karyawan akan merasa nyaman dalam bekerja dan akan berpengaruh terhadap kinerja karyawan yang 
bersangkutan. Seorang pemimpin akan mampu menyesuaikan diri dengan keadaan sekitarnya dan mampu mengendalikannya. Pemimpin juga harus mampu mengatur dan menciptakan suasana kerja yang kondusif dimana suasana kerja yang ada membuat karyawan merasa nyaman dan menumbuhkan rasa disiplin untuk menyelesaikan pekerjaan. Hal ini membawa konsekuensi bahwa setiap pimpinan berkewajiban memberikan perhatian yang sungguh-sungguh untuk membina, menggerakkan, mengarahkan semua potensi karyawan dilingkungannya agar tujuan perusahaan dapat dicapai.

Agar tujuan perusahaan bisa tercapai dan kinerja karyawan dapat ditingkatkan maka, perusahaan perlu memperhatikan kebutuhan-kebutuhan karyawannya seperti pemberian kompensasi dan fasilitasfasilitas lainnnya yang dapat memotivasi karyawan dalam menyelesaikan pekerjaannya. Kompensasi merupakan salah satu cara yang dapat diberikan perusahaan berupa imbalan kepada karyawan dalam bentuk finansial maupun nonfinansial. Pemberian kompensasi finansial dan nonfinansial kepada karyawan dimaksud sebagai upaya untuk meningkatkan kualitas kehidupan para karyawan. Kompensasi dapat meningkatkan ataupun menurunkan kinerja karyawan, Hal ini di dukung oleh penelitian yang dilakukan oleh Setiawan \& Mujiati, (2016) yang menyatakan bahwa kompensasi berpengaruh terhadap kinerja karyawan.

Semakin tinggi kompensasi yang diberikan oleh perusahaan kepada karyawan maka akan memberikan dorongan yang lebih besar terhadap kinerja karyawan, seperti halnya yang terjadi pada bisnis hotel di Kota Padang. Dimana pimpinan mencoba memberikan motivasi dan kompensasi yang layak kepada para karyawannya agar dapat mempertahankan karyawan yang baik serta meningkatkan kinerjanya. Jenis-jenis kompensasi yang diberikan oleh hotel-hotel syariah di Kota Padang yaitu berupa biaya lembur, bonus tahunan, bonus untuk karyawan berprestasi, dan lain-lain.

Dengan berkembangnya wisata syariah di kota Padang serta kebutuhan wisatawan akan tempat menginap yang nyaman seperti hotel Bunda, hotel Nabawi Syariah, hotel Musafir Inn dan beberapa hotel syariah yang lain, maka penulis memutuskan untuk meneliti hotel yang berbasis syariah. Karena keterbatasan izin penelitian maka empat hotel yang dipilih, Keempat hotel berbasis syariah tersebut adalah Hotel Sofyan Inn rangkayo Basa, Hotel Rasaki, Hotel Sriwijaya dan Hotel Abidin. Berdasarkan wawancara yang telah dilakukan, terdapat masalah pada karyawan yaitu sering terlambat datang dan tidak dipatuhinya jam kerja yang telah ditetapkan. Job description yang masih kurang jelas dan terjadinya double job yang seharusnya perusahaan jelaskan job description masing-masing karyawan agar tidak terjadi penurunan kinerja. Kurangnya motivasi dan arahan dari pimpinan yang menyebabkan kinerja karyawan menurun dan pemberian kompensasi yang dianggap masih kurang oleh karyawan terutama tunjangan-tunjangan yang seharusnya perusahaan berikan kepada karyawan seperti kompensasi finansial yang meliputi upah lembur, bonus untuk karyawan berprestasi, bonus tahunan, liburan, dan sebagainya agar kinerja karyawan dapat ditingkatkan. Kemudian karyawan juga mengeluh selama lebih kurang tiga tahun berjalan, belum adanya promosi jabatan bagi karyawan dan mereka berpendapat bahwa tidak adanya jenjang karir yang jelas bagi mereka di kemudian hari. Perusahaan seharusnya lebih memperhatikan karyawannya dengan menjelaskan kesempatan jenjang karir yang ada agar karyawan dapat memotivasi diri untuk meningkatkan kinerjanya dan meningkatkan potensi dirinya.Disisi lain, perusahaan telah memberikan fasilitas jaminan sosial untuk meningkatkan kesejahteraan karyawan, jaminan yang diberikan adalah jaminan kecelakaan kerja, dan jaminan kesehatan. Akan tetapi, fasilitas jaminan sosial yang diberikan kepada karyawan belum mampu meningkatkan kinerja karyawan karena dipengaruhi oleh aspek-aspek lainnya yang belum terpenuhi.Hal inilah yang menjadi alasan munculnya kinerja karyawan yang rendah dan tidak efektif yang berpengaruh pada kinerja sebuah perusahaan.

\section{Literature Review}

Kepemimpinan adalah upaya menggunakan berbagai jenis pengaruh yang bukan paksaan untuk memotivasi anggota organisasi agar mencapai tujuan tertentu (Gibson et al., 2014). Sedangkan menurut Siagian, (2003) kepemimpinan merupakan ketrampilan dan kemampuan seseorang untuk 
mempengaruhi orang lain, melalui komunikasi baik langsung, maupun tidak langsung dengan maksud untuk menggerakkan orang-orang tersebut agar dengan penuh pengertian dan kesadaran bersedia mengikuti kehendakkehendak pemimpin tersebut. Pengaruh pemimpin dalam menjalankan tugasnya sangat penting. Dalam mencapai berbagai tujuan organisasi baik yang bersifat tujuan ekonomi, sosial atau politik sebagian besar tergantung kepada kemampuan para pemimpin dalam unit organisasi yang bersangkutan Pengertian ini menekankan pada kemampuan seseorang dalam mempengaruhi orang lain agar melakukan suatu kegiatan atau pekerjaan, Dalam Islam pemimpin disebut dengan khalifah dimana ia adalah wakil, pengganti atau duta. Dalam pandangan Islam, kepemimpinan terkait dengan dua harapan atau tuntutan sosial mendasar yang dikenakan kepada si pemimpin. Pertama, kemampuan yang diperkirakan terdapat padanya untuk memimpin ke arah tercapainya situasi yang diinginkan oleh komunitasnya. Kedua, Kemungkinan bobot fungsinya dalam mempertahankan eksistensi komunitas .

Dalam konteks pemenuhan tuntutan sosial itu, pemimpin harus menyadari adanya pertanggungjawaban transendental, yang menghendaki keterluluhan pribadi dalam keharusan moral agama. Dalam Islam, pemimpin haruslah jujur baik kepada dirinya sendiri, maupun kepada pengikutnya, sehingga akan menjadi contoh terbaik yang sejalan antara perkataan dengan perbuatannya. Selain itu, perlu memiliki moralitas yang baik, berakhlaq terpuji, teguh memegang amanah, dan tidak suka bermaksiat seperti korupsi, manipulasi, dusta, dan khianat. Dalam islam, Kepemimpinan tanpa menyertakan values adalah sebuah kepemimpinan yang digerakkan oleh ototarianisme belaka. Nilainilai inti kehidupan yang telah teruji berlangsung sepanjang jaman adalah spiritualitas. Spiritualitas merupakan interaksi jiwa kita pada dunia sekitar, respon yang mempengaruhi perilaku kita dimanapun dan dalam kondisi apapun. Spiritualitas membantu membangun karakter dalam diri kita, Termasuk dalam pola kepemimpinan yang kita jalankan. Kepemimpinan yang berbasis spiritualitas, bukan tentang kecerdasan dan ketrampilan dalam memimpin belaka, namun juga menjunjung nilai-nilai kebenaran, kejujuran, integritas, kredibilitas, kebijaksanaan, belas kasih, yang membentuk akhlak dan moral diri sendiri dan orang lain. Kepemimpinan spiritual bukan berarti kepemimpinan yang anti intelektual, melainkan kepemimpinan spiritual sangat rasional dan juga menjernihkan rasionalitas dengan bimbingan hatinya menggunakan kecerdasan spiritual dan ketajaman mata batin.

Kompensasi merupakan sesuatu yang diterima karyawan sebagai pengganti kontribusi jasa mereka pada perusahaan. Pemberian kompensasi merupakan salah satu pelaksanaan fungsi MSDM yang berhubungan dengan semua jenis pemberian penghargaan individual sebagai pertukaran dalam melakukan tugas keorganisasian Rivai, (2016). Kompensasi merupakan semua pendapatan yang berbentuk uang, barang langsung, atau tidak langsung yang diterima karyawan sebagai imbalan atas jasa yang diberikan kepada perusahaan (Hasibuan, (2012)Sedangkan menurut Handoko, (2011) kompensasi adalah segala sesuatu yang diterima karyawan sebagai balas jasa untuk kerja mereka. Yuniarsih, et.al, (2018) mendefinisikan kompensasi sebagai segala bentuk pembayaran atau imbalan yang diberikan kepada karyawan oleh perusahaan sebagai balas jasa atas kontribusi mereka kepada perusahaan.

Dalam pandangan Islam, kompensasi dapat dikaitkan dengan imbalan yang diterima seseorang atas pekerjaannya dalam bentuk imbalan materi (di dunia) dan dalam bentuk imbalan pahala (di akhirat) secara adil dan layak. Osman-Gani, et.al (2013) mengemukakan bahwa Islam menekankan bahwa pekerja diberikan gaji yang cukup dan yang rasional untuk pekerjaan mereka, dalam sudut pandang kualitas dan kuantitas pekerjaan, berdasarkan kebutuhan dan permintaan, dan kondisi ekonomi di masyarakat. Islam dengan tegas melarang kekerasan dan paksaan terhadap pekerja. Islam juga memandang kompensasi (upah) merupakan hal yang sangat penting dalam menjalankan usaha. Bahkan dalam sebuah Hadits disebutkan yang artinya "bayarlah upah (kerja) mereka sebelum kering keringatnya". Dari hadits tersebut dapat disimpulkan bahwa Islam sangat mengedepankan kompensasi dimana ia adalah hak utama seorang pekerja karena pekerjaan yang telah dilakukan dan pemberi kerja wajib untuk membayar upah pekerja tersebut dengan segera dan nilai yang pantas. Ajaran Islam sangat peduli kepada keberadaan karyawan, sebagai bentuk kepedulian kepada dunia kerja, karena Islam menginginkan umatnya untuk giat bekerja, sehingga mereka akan memperoleh hasil yang halal dari pekerjaannya.

Kinerja kinerja berasal dari Job performance atau Actual Performance (prestasi kerja atau prestasi sesungguhnya yang dicapai seseorang) kinerja adalah hasil kerja secara kualitas dan kuantitas yang 
dicapai oleh seorang pegawai dalam melaksanakan tugasnya sesuai dengan tanggung jawab yang diberikan kepadanya (Mangkunegara, 2003)

Ada berbagai pendapat tentang kinerja tersebut, seperti yang disarankan oleh (Byars \& Rue, 2011). Dikatakan bahwa kinerja adalah hasil dari tingkat pencapaian. Kinerja adalah kualitas perilaku berorientasi tugas atau pekerjaan (Murphy \& Cleveland, 1995). Ndraha, (1989) mengatakan bahwa pertunjukan tersebut adalah manifestasi populis dari hubungan antara masyarakat dan pemerintah.

Kinerja merupakan perilaku manusia dalam suatu organisasi yang memenuhi standar perilaku yang ditetapkan untuk mencapai hasil yang diinginkan. Kinerja merupakan derajat penyelesaian tugas yang menyertai pekerjaan seseorang. Sumbangan yang terbesar bagi perusahaan demi tercapainya kinerja perusahaan yang optimal serta fungsi-fungsi perusahaan dapat dilihat berdasarkan kinerja karyawan (Akbar, 2018). Kinerja karyawan merupakan kesuksesan seseorang dalam melaksanakan suatu pekerjaan dimana kinerja pada dasarnya hasil kerja seseorang karyawan selama periode tertentu. Kinerja adalah yang merefleksikan seberapa baik seseorang individu memenuhi permintaan pekerjaan.

Faktor-Faktor Yang Mempengaruhi Pencapaian Kinerja

Dalam mengetahui tingkat kinerja seorang karyawan dalam suatu perusahaan, ada beberapa faktor yang dapat mempengaruhinya. Seperti yang dikemukakan oleh Mangkunegara, (2003), antara lain:

a. Faktor Kemampuan (Ability) Secara psikologis, kemampuan (ability) pegawai terdiri dari kemampuan potensi atau Intelligence Quotient (IQ) dan kemampuan realiti (knowledge + skill) artinya, setiap pegawai yang memiliki IQ di atas rata-rata dengan pendidikan yang memadai untuk jabatannya dan terampil dalam mengerjakan pekerjaannya, maka ia akan lebih mudah mencapai kinerja yang diharapkan. Oleh karena itu, pegawai perlu ditempatkan sesuai dengan keahliannya.

b. Faktor Motivasi (Motivation) Motivasi terbentuk dari sikap seorang pegawai dalam menghadapi situasi kerja. Motivasi merupakan kondisi yang menggerakkan diri pegawai yang terarah untuk mencapai tujuan organisasi. Sikap, sikap mental yang mendorong diri pegawai untuk berusaha mencapai kinerja secara maksimal. Sikap mental seseorang pegawai harus sikap mental yang siap secara psikofisik (siap secara mental, fisik, tujuan, dan situasi). Artinya, seorang pegawai harus memiliki sikap mental, mampu secara fisik, memahami tujuan utama dan target kerja yang akan dicapai, mampu memanfaatkan, dan menciptakan situasi kerja.

David C. Mc Clelland dalam Mangkunegara, (2003), berpendapat bahwa ada hubungan positif antara motif berprestasi dengan pencapaian kinerja. Motif berprestasi adalah suatu dorongan dalam diri pegawai untuk melakukan suatu kegiatan atau tugas dengan sebaik-baiknya agar mampua mencapai kinerja yang maksimal. Pegawai akan mampu mencapai kinerja maksimal apabila pegawai tersebut memiliki motif berprestasi tinggi. Motif berprestasi tersebut perlu dimiliki oleh pegawai yang ditumbuhkan dari dalam diri sendiri selain dari lingkungan kerja.

\section{Metode Penelitian}

Jenis Penelitian ini merupakan penelitian asosiatif kausal dengan menggunakan pendekatan kuantitatif. Menurut Umar, (2005) penelitian asosiatif kausal adalah penelitian yang bertujuan untuk menganalisis hubungan antara satu variabel dengan variabel lainnya atau bagaimana suatu variabel mempengaruhi variabel lainnya. Menurut Kuncoro, (2003) mengggunakan pendekatan kuantitatif karena data yang digunakan dinyatakan dengan angka atau skala numerik. Penelitian ini menganalisis pengaruh kepemimpinan dan kompensasi terhadap kinerja karyawan pada hotel syariah di kota Padang.

Unit analisis merupakan karyawan hotel syariah di kota Padang yaitu Hotel Rangkayo Basa, Hotel Sriwijaya, Hotel Abidin, dan Hotel Rasaki, Penelitian ini tidak digunakan teknik sampling karena sampel yang diteliti adalah keseluruhan dari populasi yang ada atau disebut dengan sensus. Mengenai sensus Ruslan (2014) mengatakan bahwa alasan melakukan sensus, yaitu peneliti sebaiknya mempertimbangkan untuk meneliti seluruh elemen-elemen dari populasi, jika elemen populasi relatif sedikit dan variabilitas setiap elemennya yang tinggi (heterogen). Sensus lebih layak dilakukan jika penelitian yang dimaksudkan untuk menjelaskan karakteristik setiap elemen dari suatu populasi, maka 
jumlah sampel yang diambil dalam penelitian ini sebanyak 104 karyawan. Dimana sampel yang dipilih adalah seluruh karyawan di empat hotel syariah di Kota Padang (Hotel Rangkayo Basa 35 orang karyawan, Hotel Rasaki 35 orang karyawan, Hotel Sriwijaya 21 orang karyawan, dan Hotel Abidin sebanyak 13 orang karyawan)

\section{Tabel 1}

\section{Defenisi operasional Variabel}

\begin{tabular}{|c|c|c|}
\hline Variabel & Konsep Variabel & Indikator \\
\hline $\begin{array}{l}\text { Kepemimpian } \\
\text { (X1) }\end{array}$ & $\begin{array}{l}\text { kepemimpinan adalah upaya menggunakan } \\
\text { berbagai jenis pengaruh yang bukan paksaan untuk } \\
\text { memotivasi anggota organisasi agar mencapai } \\
\text { tujuan tertentu. (Gibson,2003). }\end{array}$ & $\begin{array}{l}\text { 1. Iklim saling } \\
\text { mempercayai } \\
\text { 2. Penghargaan terhadap } \\
\text { ide bawahan } \\
\text { 3. Memperhitungkan } \\
\text { perasaan para bawahan } \\
\text { 4. Perhatian pada } \\
\text { kenyamanan kerja bagi } \\
\text { para bawahan } \\
\text { 5. Perhatian pada } \\
\text { kesejahteraan bawahan } \\
\text { 6. Memperhitungkan } \\
\text { faktor kepuasan kerja } \\
\text { para bawahan dalam } \\
\text { menyelesaikan tugas- } \\
\text { tugas yang } \\
\text { dipercayakan } \\
\text { kepadanya. } \\
\text { 7. Pengakuan atas status } \\
\text { para bawahan secara } \\
\text { tepat dan profesional. }\end{array}$ \\
\hline $\begin{array}{l}\text { Kompensasi } \\
\text { (X2) }\end{array}$ & $\begin{array}{l}\text { kompensasi sebagai segala bentuk pembayaran } \\
\text { atau imbalan yang diberikan kepada karyawan oleh } \\
\text { perusahaan sebagai balas jasa atas kontribusi } \\
\text { mereka kepada } \\
\text { (Yuniarsih\&Suwatno,2009). }\end{array}$ & $\begin{array}{l}\text { 1. Gaji } \\
\text { 2. Upah insentif } \\
\text { 3. Asuransi } \\
\text { 4. Fasilitas kantor } \\
\text { 5. Tunjangan }\end{array}$ \\
\hline $\begin{array}{l}\text { Kinerja } \\
\text { Karyawan } \\
\quad(\mathbf{Y})\end{array}$ & $\begin{array}{l}\text { kinerja adalah hasil kerja secara kualitas dan } \\
\text { kuantitas yang dicapai oleh seorang pegawai dalam } \\
\text { melaksanakan tugasnya sesuai dengan tanggung } \\
\text { jawab yang diberikan kepadanya. (Mangkunegara, } \\
\text { 2011) }\end{array}$ & $\begin{array}{ll}\text { 1. } & \text { Kualitas Kerja } \\
\text { 2. Kuantitas kerja } \\
\text { 3. } \\
\text { 4. } & \text { Sikgap Karyawan Jawab }\end{array}$ \\
\hline
\end{tabular}

Metode pengumpulan data dengan mengadakan wawancara secara langsung kepada objek untuk memperoleh data yang diperlukan sesuai dengan kuisioner yang telah disampaikan. Menurut Sugiyono, (2016), kuesioner merupakan teknik pengumpulan data yang dilakukan dengan cara memberi seperangkat pertanyaan atau pernyataan tertulis kepada responden untuk dijawab.

Berdasarkan tinjauan landasan teori dan penelitian terdahulu, maka dapat disusun suatu kerangka pemikiran dalam penelitian ini. Seperti yang terlihat pada gambar berikut ini

\section{Gambar 1}

\section{Frame work}




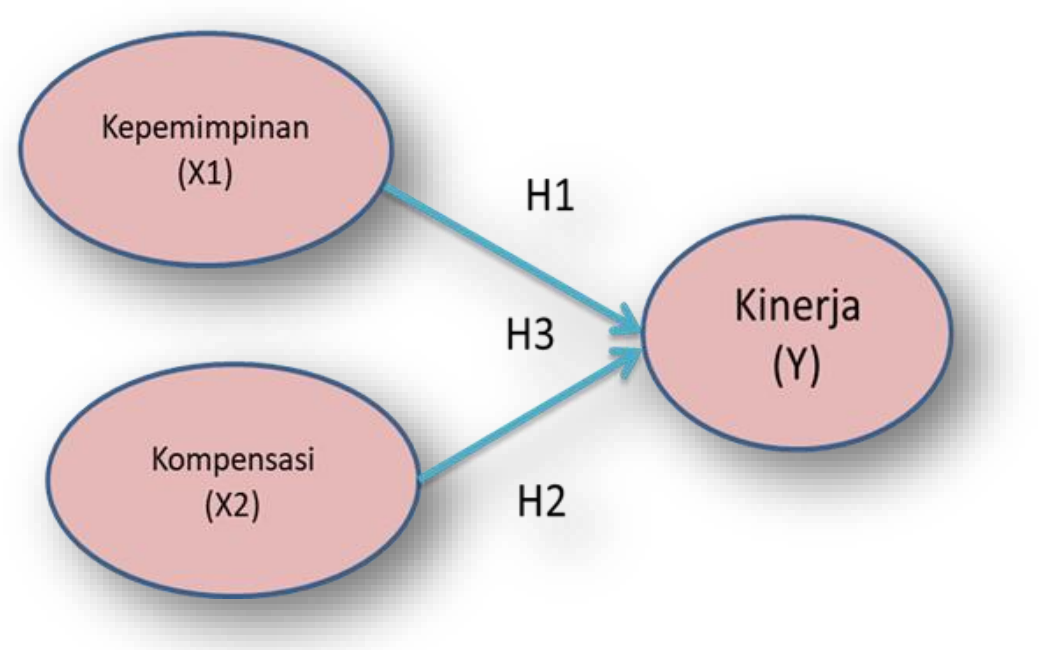

Hipotesis merupakan suatu pernyataan yang kedudukannya belum sekuat proposisi atau hasil. Sesuai dengan variabel-variabel yang akan diteliti maka hipotesis yang akan di uji dalam penelitian ini berkaitan atau tidaknya pengaruh signifikan dari variabel-variabel bebas terhadap variabel terikat.

H1 : Diduga kepemimpinan berpengaruh positif dan signifikan terhadap kinerjakaryawan hotel syariah di Kota Padang.

H2 : Diduga kompensasi berpengaruh positif dan signifikan terhadap kinerja karyawan hotel syariah di Kota Padang..

H3: Diduga kepemimpinan dan kompensasi secara simultan berpengaruh positif dan signifikan terhadap kinerja karyawan pada hotel syariah di Kota Padang.

\section{Hasil Dan Pembahasan}

Responden dalam penelitian ini berjumlah sebanyak 104 karyawan. Dimana sampel yang dipilih adalah seluruh karyawan di empat hotel syariah di Kota Padang (Hotel Rangkayo Basa 35 orang karyawan, Hotel Rasaki 35 orang karyawan, Hotel Sriwijaya 21 orang karyawan, dan Hotel Abidin sebanyak 13 orang karyawan). Data dikumpulkan melalui penyebaran kuesioner kepada sejumlah responden yang menjadi sampel dalam penelitian ini. Penelitian sampel dilakukan dengan terlebih dahulu memastikan bahwa responden adalah karyawan hotel syariah. Penyajian data mengenai identitas responden dalam penelitian ini yaitu untuk memberikan gambaran tentang keadaan diri pada responden. Adapun gambaran tentang responden yang menjadi sampel dalam penelitian ini diklasifikasikan berdasarkan jenis kelamin, status, umur, jabatan, masa kerja dan pendidikan terakhir. Berikut ini akan dibahas mengenai kondiri dari masing-masing demografis responden tersebut.

Tabel 2

Responden Berdasarkan Jenis Kelamin

\begin{tabular}{|c|c|c|c|}
\hline No & Jenis Kelamin & Jumlah & Frekuensi \\
\hline 1 & Laki-Laki & 64 & $61,53 \%$ \\
\hline 2 & Perempuan & 40 & $38,47 \%$ \\
\hline \multicolumn{2}{|c|}{ Total } & 104 & $100 \%$ \\
\hline
\end{tabular}


Hasil penelitian menunjukkan bahwa proporsi pengelompokkan karyawan berdasarkan jenis kelamin seperti yang tertera pada Tabel 2 diatas, dimana proporsi terbesar yaitu karyawan yang berjenis kelamin laki-laki yaitu dengan persentase $61,53 \%$, sedangkan karyawan perempuan lebih sedikit dari karyawan laki-laki, yaitu 38,47\%. Hal ini dikarenakan karyawan laki-laki lebih dibutuhkan tenaganya untuk bekerja pada shift sore dan malam, manakala Karyawan perempuan lebih sedikit dari pada karyawan laki-laki karena pada hotel syariah di kota padang karyawan perempuan hanya dipekerjakan pada shift pagi.

Tabel 3

Responden Berdasarkan Pendidikan Terakhir

\begin{tabular}{|c|c|c|c|}
\hline No & Pendidikan Terakhir & Jumlah & Frekuensi \\
\hline 1 & SMA/SMK sederajat & 61 & $58,65 \%$ \\
\hline 2 & Diploma & 38 & $36,54 \%$ \\
\hline 3 & Strata & 5 & $4,81 \%$ \\
\hline & Total & 104 & $100 \%$ \\
\hline
\end{tabular}

Hasil penelitian menunjukkan bahwa proporsi pengelompokkan karyawan berdasarkan pendidikan terakhir seperti yang tertera pada Tabel 3 diatas, dimana proporsi terbesar yaitu karyawan yang pendidikan terakhirnya adalah SMA dengan persentase 58,63\% sedangkan proporsi terendah yaitu karyawan dengan pendidikan terakhir Strata dengan persentase 4,81\%. Karyawan yang pendidikan terakhirnya SMA lebih banyak dari yang tamatan diploma dan strata karena di hotel syariah kota padang hanya sedikit membutuhkan karyawan pada posisi $\neg$ back office seperti orang yang bertugas mengurusi laporan keuangan, dan laporan penjualan.

Tabel 4

Responden Berdasarkan Masa Kerja

\begin{tabular}{|c|c|c|c|}
\hline No & Masa Kerja & Jumlah & Frekuensi \\
\hline 1 & $<1$ tahun & 25 & $24,04 \%$ \\
\hline 2 & $1-3$ tahun & 42 & $40,39 \%$ \\
\hline 3 & $3-5$ tahun & 27 & $25,96 \%$ \\
\hline 4 & $>5$ tahun & 10 & $9,61 \%$ \\
\hline \multicolumn{2}{|c|}{ Total } & 104 & $100 \%$ \\
\hline
\end{tabular}

Hasil penelitian menunjukkan bahwa proporsi pengelompokkan karyawan berdasarkan masa kerja seperti yang tertera pada Tabel 4 diatas, dimana proporsi terbesar yaitu karyawan yang masa kerjanya diantara 1-3 tahun dengan persentase $40,39 \%$ sedangkan proporsi terendah yaitu karyawan dengan masa kerja $>5$ tahun dengan persentase $9,61 \%$.

Tabel 5

Responden Berdasarkan Usia

\begin{tabular}{|c|c|c|c|}
\hline No & Usia & Jumlah & Frekuensi \\
\hline 1 & $<25$ tahun & 16 & $15,38 \%$ \\
\hline 2 & $26-30$ tahun & 44 & $42,32 \%$ \\
\hline 3 & $31-35$ tahun & 22 & $21,15 \%$ \\
\hline
\end{tabular}




\begin{tabular}{|c|c|c|c|}
\hline 4 & $>35$ tahun & 22 & $21,15 \%$ \\
\hline \multicolumn{2}{|c|}{ Jumlah } & 104 & $100 \%$ \\
\hline
\end{tabular}

Hasil penelitian menunjukkan bahwa proporsi pengelompokkan karyawan berdasarkan umur seperti yang tertera pada Tabel 5 diatas, dimana proporsi terbesar yaitu karyawan yang berumur diantara 26-30 tahun dengan persentase $42,32 \%$ sedangkan proporsi terendah yaitu karyawan dengan umur < 25 tahun dengan persentase $15,38 \%$.

Hal ini dikarenakan rata-rata karyawan yang berada pada bagian departemen food beverage berusia 26-30 tahun dengan masa kerja paling dominan berkisar 1-3 tahun.

Tabel 6

Responden Berdasarkan Status Pernikahan

\begin{tabular}{|c|c|c|c|}
\hline No & Status & Jumlah & Frekuensi \\
\hline 1 & Belum Menikah & 58 & $55,77 \%$ \\
\hline 2 & Menikah & 46 & $44,23 \%$ \\
\hline \multicolumn{2}{|c|}{ Total } & Jumlah & 104 \\
\hline
\end{tabular}

Hasil penelitian menunjukkan bahwa proporsi pengelompokkan karyawan berdasarkan status seperti yang tertera pada Tabel 6 diatas, dimana proporsi terbesar yaitu karyawan dengan status belum menikah dengan persentase $55,77 \%$ sedangkan proporsi terendah yaitu karyawan yang berstatus menikah dengan persentase $44,23 \%$.

Persentase status belum menikah lebih tinggi dari persentase status nikah karena karyawan hotel syariah rata-rata adalah lelaki dan umur mereka berkisar 26-30 tahun.

Tabel 7

Responden Berdasarkan Jabatan Pekerjaan

\begin{tabular}{|c|c|c|c|}
\hline No & Departemen / bagian & Jumlah & Frekuensi \\
\hline 1 & Driver & 3 & $2,87 \%$ \\
\hline 2 & Front Office & 11 & $10,58 \%$ \\
\hline 3 & House Keeping & 25 & $24,05 \%$ \\
\hline 4 & Waiter & 1 & $0,96 \%$ \\
\hline 5 & Chef & 1 & $0,96 \%$ \\
\hline 6 & Security & 3 & $2,87 \%$ \\
\hline 7 & Engineering & 13 & $12,6 \%$ \\
\hline 8 & Linen & 16 & $15,39 \%$ \\
\hline 9 & Food Beverage & 31 & $29,81 \%$ \\
\hline
\end{tabular}




\begin{tabular}{|l|c|c|}
\hline Jumlah & 104 & $100 \%$ \\
\hline
\end{tabular}

Hasil penelitian menunjukkan bahwa proporsi pengelompokkan karyawan berdasarkan jabatan seperti yang tertera pada Tabel 7 diatas, dimana proporsi terbesar yaitu karyawan dengan jabatan sebagai food beverage yang memiliki persentase $29,81 \%$ sedangkan proporsi terendah yaitu karyawan dengan jabatan waiter dan chef persentase $0,96 \%$.

Hal ini dikarenakan Food beverage adalah bagian penyediaan dan pelayanan makanan dan minuman serta kebutuhan lain yang terkait, dimana mempunyai persentase lebih besar karena ia adalah bagian yang sangat mutlak diperlukan di hotel dalam memenuhi kebutuhan para tamu yang datang ke hotel.

Uji Validitas dari 35 item pertanyaan yang digunakan untuk mengukur Kepemimpinan, Kompensasi dan Kinerja karyawan, masing-masing item peryatan tersebut menghasilkan koefisien corrected item total corelatioan $>0,30$. Oleh sebab itu seluruh item pertanyaan yang valid dapat terus digunakan kedalam tahapan pengolahan data selanjutnya.

Uji Reliabilitas Dari tabel 8 terlihat masing-masing variabel yang akan diuji yaitu terdiri dari Kepemimpinan, Kompensasi dan Kinerja karyawan yang telah memiliki cronbach alpha diatas 0,60 sehingga dapat disimpulkan masing-masing variabel tersebut telah didukung oleh item pertanyaan yang valid dan reliable oleh sebab itu dapat terus digunakan kedalam tahapan pengolahan data lebih lanjut

\section{Tabel 8}

\section{Hasil Uji Reliabilitas}

\begin{tabular}{|l|l|c|c|c|}
\hline No. & \multicolumn{1}{|c|}{ Variabel } & $\begin{array}{c}\text { Cronbach } \\
\text { alpha }\end{array}$ & Cut Off & Kesimpulan \\
\hline 1. & Kepemimpinan (X1) & 0,844 & 0,60 & Reliable \\
\hline 2. & Kompensasi (X2) & 0,812 & 0,60 & Reliable \\
\hline 3. & Kinerja Karyawan (Y) & 0,772 & 0,60 & Reliable \\
\hline
\end{tabular}

Regresi Linier Berganda Dalam analisis regresi, selain mengukur kekuatan pengaruh antara dua variabel atau lebih, juga menunjukkan pengaruh antara variabel independen dengan variabel dependen.

Tabel 9

Uji Regresi Linier Berganda

Coefficients $^{\mathrm{a}}$

\begin{tabular}{|c|c|c|c|c|c|c|}
\hline \multirow{2}{*}{\multicolumn{2}{|c|}{ Model }} & \multicolumn{2}{|c|}{ Unstandardized Coefficients } & \multirow{2}{*}{$\begin{array}{c}\begin{array}{c}\text { Standardized } \\
\text { Coefficients }\end{array} \\
\text { Beta }\end{array}$} & \multirow[t]{2}{*}{$\mathrm{t}$} & \multirow[t]{2}{*}{ Sig. } \\
\hline & & $\mathrm{B}$ & Std. Error & & & \\
\hline \multirow{3}{*}{1} & (Constant) & 8.986 & 4.345 & & 2.068 & .0 \\
\hline & Kepemimpinan & .477 & .062 & .605 & 7.710 & .0( \\
\hline & Kompensasi & .165 & .078 & .167 & 2.128 & .036 \\
\hline
\end{tabular}


Dari tabel 9 diatas diperoleh persamaan sebagai berikut:

$\mathrm{Y}=\mathrm{a}+\mathrm{b} 1 \mathrm{X}_{1}+\mathrm{b} 2 \mathrm{X}_{2}+\mathrm{e}$

$\mathrm{Y}=8,986+0,477 \mathrm{X}_{1}+0,165 \mathrm{X}_{2}+\mathrm{e}$

Interpretasi persamaan diatas :

1) Nilai konstanta sebesar 8,986 menunjukkan bahwa tanpa adanya pengaruh kepemimpinan (X1), kompensasi (X2) maka kinerja karyawan (Y). nilainya positif sebesar 8,986.

2) Variabel kepemimpinan (X1) memiliki koefisien regresi positif sebesar $\left(b_{1}=0,477\right)$, berarti variabel kepemimpinan (X1) memiliki hubungan yang positif dengan kinerja karyawan (Y) hotel syariah di Kota Padang. Hal ini menunjukkan jika sikap pimpinan baik, maka kinerja karyawan akan naik sebesar 0,477 satuan, sedangkan variabel yang lain tetap.

3) Variabel kompensasi (X2), memiliki koefisien regresi positif sebesar $\left(b_{2}=0,165\right)$, berarti variabel kompensasi memiliki hubungan yang positif dengan kinerja karyawan hotel syariah dikota Padang. Hal ini menunjukkan jika perusahaan memperhatikan kompensasi sebagai stimulus bagi karyawan, maka kinerja karyawan akan naik sebesar 0,165 satuan, sedangkan variabel yang lain tetap.

Tabel 10

Uji Koefisien Determinasi (R2)

\section{Model Summary}

\begin{tabular}{|l|c|r|r|r|}
\hline Model & R & R Square & \multicolumn{1}{|c|}{$\begin{array}{c}\text { Adjusted R } \\
\text { Square }\end{array}$} & $\begin{array}{c}\text { Std. Error of the } \\
\text { Estimate }\end{array}$ \\
\hline 1 & $0.617^{3}$ & 0.381 & 0.368 & 3.55878 \\
\hline
\end{tabular}

Dalam tabel 10 (model summary) ini menunjukkan bahwa koefisien determinasi ( $R$ Square) sebesar 0,381 dan nilai koefisien determinasi yang telah disesuaikan (Adjusted $R$ Square) sebesar 0,368. Hal ini berarti 36,8 \% variabel dependen kinerja karyawan hotel syariah di Kota Padang (Y) dapat dijelaskan oleh variabel independen pimpinan (X1) dan kompensasi (X2) Sedangkan sisanya 63,2 \% dipengaruhi oleh faktor-faktor lain yang tidak diteliti dalam penelitian ini.

\section{Uji Hipotesis \\ Uji Parsial (Uji t)}

Tabel 11

Hasil Uji t

Coefficients $^{\mathrm{a}}$

\begin{tabular}{|l|r|c|c|c|c|c|c|}
\hline Model & \multicolumn{2}{|c|}{$\begin{array}{c}\text { Unstandardized } \\
\text { Coefficients }\end{array}$} & $\begin{array}{c}\text { Standardize } \\
\mathrm{d} \\
\text { Coefficients }\end{array}$ & $\mathrm{t}$ & \multicolumn{2}{|l|}{ Sig. } & \multicolumn{2}{|l|}{ Collinearity Statistics } \\
\cline { 2 - 4 } & $\mathrm{B}$ & $\begin{array}{c}\text { Std. } \\
\text { Error }\end{array}$ & Beta & & & Tolerance & VIF \\
\hline $1 \quad$ (Constant) & 8.986 & 4.345 & & 2.068 & .041 & & \\
\hline
\end{tabular}




\begin{tabular}{|l|r|r|r|r|r|r|r|}
\hline Kepemimpina & .477 & .062 & .605 & 7.710 & .000 & .995 & 1.005 \\
$\mathrm{n}$ & & & & & & & \\
Kompensasi & .165 & .078 & .167 & 2.128 & .036 & .995 & 1.005 \\
\hline
\end{tabular}

Berdasarkan hasil uji parsial untuk kepemimpinan (X1) dan kompensasi (X2) maka dapat dijelaskan sebagai berikut :

1) H1 menyatakan kepemimpinan berpengaruh terhadap kinerja. Berdasarkan analisis data pengujian $\mathrm{H} 1$ menunjukkan $\mathrm{t}_{\text {hitung }}$ sebesar 7,710 Probabilitas kesalahan sebesar $0,00<0,05$ dengan demikian $\mathrm{t}_{\text {hitung }}$ berada pada daerah $\mathrm{H} 0$ ditolak dan Ha diterima maka angka tersebut menunjukkan nilai yang signifikan yang artinya terdapat kepemimpinan terhadap kinerja karyawan karyawan pada hotel syariah dikota Padang. Pernyataan H1 diterima. Pengaruh positif sebesar 0,477 artinya jika semakin baik pemimpin dalam suatu organisasi maka kinerja karyawan akan semakin baik juga.

2) $\mathrm{H} 2$ menyatakan kompensasi berpengaruh terhadap kinerja karyawan. Berdasarkan analisis data pengujian $\mathrm{H} 2$ menunjukkan $\mathrm{t}_{\text {hitung }}$ sebesar 2,128. Probabilitas kesalahan sebesar 0,036 $<0,05$ dengan demikian $\mathrm{t}_{\text {hitung }}$ berada pada daerah $\mathrm{HO}$ ditolak dan Ha diterima maka angka tersebut menunjukkan nilai yang signifikan yang artinya terdapat kompensasi terhadap kinerja karyawan hotel syariah dikota Padang. Pernyataan $\mathrm{H} 2$ diterima. Pengaruh positif sebesar 0,165 artinya jika jika kompensasi yang diterima karyawan semakin banyak maka akan berpengaruh terhadap peningkatan kinerja karyawan.

\section{Uji Simultan (Uji F)}

Tabel 12

Uji Simultan

ANOVA $^{\mathrm{a}}$

\begin{tabular}{|rl|r|r|r|r|r|}
\hline \multicolumn{1}{|l|}{ Model } & \multicolumn{1}{c|}{$\begin{array}{l}\text { Sum of } \\
\text { Squares }\end{array}$} & df & Mean Square & F & Sig. \\
\hline \multirow{2}{*}{1} & Regression & 785.726 & 2 & 392.863 & 31.020 & $.000^{2}$ \\
& Residual & 1279.159 & 101 & 12.665 & & \\
& Total & 2064.885 & 103 & & & \\
\hline
\end{tabular}

Dari uji ANOVA atau F test di dapat nilai $\mathrm{F}$ hitung sebesar 31, 020 dengan tingkat probabilitas signifikasi 0,000. Karena probabilitas signifikan jauh lebih kecil dari $0.05(0,000<0,05)$ maka Ho di tolak dan Ha diterima.

Hal ini berarti variabel kepemimpinan (X1) dan kompensasi (X2) secara bersama-sama atau simultan berpengaruh signifikan terhadap kinerja karyawan (Y) hotel syariah di Kota Padang.

\section{Penutup}

\section{Simpulan}

Berdasarkan pada analisis dan pembahasan hasil pengujian hipotesis yang telah dilakukan, maka dapat disimpulkan hasil penelitian yang merupakan pemecahan masalah dari sejumlah pertanyaan yang diajukan dalam penelitian ini adalah sebagai berikut :

1. Kepemimpinan (X1) dengan tingkat signifikansi lebih kecil dari alpha $(0,000<0,05)$ maka Ho ditolak dan Ha diterima, Sehingga dari hasil uji t tersebut dapat dikatakan bahwa variabel kepemimpinan secara parsial berpengaruh positif dan signifikan terhadap kinerja karyawan hotel syariah di Kota Padang.

2. Kompensasi $(\mathrm{X} 2)$ dengan tingkat signifikansi lebih kecil dari alpha $(0,036<0,05)$ maka Ho ditolak dan Ha diterima, Sehingga dari hasil uji t tersebut dapat dikatakan bahwa variabel kompensasi secara parsial berpengaruh positif dan signifikan terhadap kinerja karyawan hotel syariah di Kota Padang. 
3. Berdasarkan pada hasil pengolahan data menunjukkan nilai $F$ hitung sebesar 31,020 dengan tingkat probabilitas signifikasi 0,000 . Karena probabilitas signifikan jauh lebih kecil dari $0.05(0,000<$ 0,05) maka Ho di tolak dan Ha diterima. Maka dapat dikatakan Kepemimpinan (X1) dan Kompensai (X2) secara bersama-sama atau simultan berpengaruh signifikan terhadap Kinerja karyawan (Y) hotel syariah di Kota Padang

\section{Saran}

1. Hendaknya Pihak hotel selalu berupaya untuk menggunakan model Kepemimpinan yang sesuai dengan karakteristik syariah.

2. Pihak hotel hendaknya selalu memperhatikan kompensasi yang diberikan kepada karyawannya 


\section{DAFTAR PUSTAKA}

Akbar, S. (2018) 'Analisa Faktor-Faktor Yang Mempengaruhi Kinerja Karyawan', JIAGANIS, 3(1).

Byars, L. L. and Rue, L. W. (2011) Human Resource Management, Eight Edition, The McGraw-Hill Companies.

Faisal, H. (2017) 'Tahun Ini, Industri Perhotelan Sumbar Lebih Optimistis'. Available at: https://kabar24.bisnis.com/read/20170129/78/623774/tahun-ini-industri-perhotelan-sumbarlebih-optimistis.

Gibson, J. L. et al. (2014) Organizations - Behavior, Structurem Processes, Igarss 2014.

Handoko, T. H. (2011) 'Manajemen Personalia dan Sumber Daya Manusia', Pengantar Manajemen.

Kuncoro (2003) Metode riset untuk bisnis \& ekonomi, Metodologi penelitian.

Malayu S.P Hasibuan (2012) Manajemen Sumber Daya Manusia, Jakarta: PT.Bumi Aksara.

Mangkunegara, A. A. A. P. (2003) Manajemen Sumber Daya Manusia Perusahaan, Remaja Rosdakarya.

Murphy, K. R. and Cleveland, J. N. (1995) Understanding performance appraisal: Social, organizational, and goal-based perspectives. Sage.

Ndraha, T. (1989) Konsep Administrasi dan Administrasi di Indonesia. Bina Aksara.

Osman-Gani, A. M., Hashim, J. and Ismail, Y. (2013) 'Establishing linkages between religiosity and spirituality on employee performance', Employee Relations.

Rivai, V. (2016) 'Manajemen sumber daya manusia untuk perusahaan'. Rajawali Pers.

Ruslan, Rosady, SH, M. (2014) 'Manajemen Public Relations \& Media Komunikasi.', in Manajemen Public Relations \& Media Komunikasi.

Sainaghi, R. (2010) 'Hotel performance: State of the art', International Journal of Contemporary Hospitality Management.

Setiawan, K. A. and Mujiati, N. W. (2016) 'Pengaruh Gaya Kepemimpinan Dan Kompensasi Terhadap Kinerja Karyawan Pt. Astra Honda Nusa Dua Kabupaten Badung', E-Jurnal Manajemen, 5(12).

Siagian, S. P. (2003) ‘Teori dan Praktek Kepemimpinan', Jakarta: Rineka Cipta.

Sofyan, R. (2011) Bisnis syariah, mengapa tidak?: pengalaman penerapan pada bisnis hotel. Gramedia Pustaka Utama.

Sugiyono (2016) Metodologi Penelitian Kuantitatif, Kualitatif, dan R\&D, CV Alfabeta.

Umar, H. (2005) Metode Penelitian untuk Tesis Bisnis, Gramedia Pustaka Utama.

Wingett, F. et al. (2018) 'Halal holidays : exploring expectations of Muslim-friendly holidays'.

Yuniarsih, T., Suwatno and Adman (2018) Manajemen Sumber Daya Manusia, Bandung : Alfabeta. 